\title{
Home Office: Ergonomia na nova forma de morar e trabalhar
}

Ludmilla Pinto Bragança Moreno';

Raimundo Lopes Diniz ${ }^{2}$;

\section{Resumo:}

As novas tecnologias de comunicação são uma das características marcantes da sociedade contemporânea nesta era de globalização. Tais recursos advindos da cibercultura modificam gradativamente e significativamente as interações humano-máquina-ambiente (IIDA e BUARQUE, 2016). De acordo com Requena (2007) vive-se uma Era em que houve a expansão do habitar, criando uma nova forma de morar: um habitar híbrido; isto é, o espaço físico da residência em congruência com o espaço do meio virtual das tecnologias da informação, que hoje ligam a todos os usuários. Esta nova relação humano-máquina-ambiente se conecta não apenas com o morar, mas também se relaciona intimamente com as relações de trabalho, uma vez que este avanço tecnológico proporcionou suporte para adaptações do trabalho a serem realizadas à distância (OLIVEIRA 1996). O trabalho à distância pode ser conceituado como atuações profissionais efetivadas fora do ambiente da empresa e/ou escritório, o qual possui a possibilidade de se comunicar através das tecnologias de qualquer tipo, como por exemplo: e-mail (WIRTH e DI MARTINO, 1990). Dentre as formas de organização que o trabalho remoto pode adotar, tem-se o denominado Home Office: caracterizado por efetuar atividades profissionais no mesmo ambiente em que se reside (SANTOS 2012). Nos últimos anos, principalmente a partir do ano de 2020, este modelo de produção de trabalho tem se tornado imprescindível, uma vez que as relações humanas tiveram que ser minimizadas, devido à pandemia oriunda da disseminação do coronavírus e o consequente aumento do desemprego (AGÊNCIA BRASIL 2020). Diante do exposto, buscando promover a qualidade de vida do cidadão e sua adaptação a uma nova forma de trabalhar e morar, emerge a questão da pesquisa: como a ergonomia pode auxiliar o usuário na execução do Home Office? A análise ergonômica consiste, segundo Iida e Buarque (2016), no estudo da adaptação do trabalho ao ser humano, assim, afim de melhorar a forma de projetar este tipo de ambiente, faz-se necessário uma intervenção ergonômica durante o processo de seu planejamento. A pesquisa caracterizada como aplicada, descritiva e exploratória, com abordagem qualitativa, possui por objetivo analisar o papel da ergonomia para auxiliar o usuário na execução de Home Office, tendo como partida o aperfeiçoamento do seu ambiente de trabalho assim como os produtos que utiliza. Portanto, para o alcance do objetivo, define-se como procedimento metodológico o Método de Análise do Ambiente Construído (MEAC) de Villarouco (2007), a qual consiste em verificar a adequação ergonômica de espaços construídos em duas fases: a primeira fase é de ordem física (análise global do ambiente, identificação da configuração ambiental e avaliação do ambiente em uso no desenvolvimento das atividades) e a segunda fase é de caráter cognitivo do usuário (percepção ambiental, diagnóstico ergonômico do ambiente e proposições ergonômicas para o ambiente). Assim, faz-se importante frisar os resultados esperados: otimizar o sistema e favorecer a produtividade, minimizar os problemas/constrangimentos ergonômicos da ordem física, cognitiva e organizacional (como doenças ocupacionais, estresse e irritabilidade) através da transformação da interação do usuário com o

\footnotetext{
${ }^{1}$ http://lattes.cnpq.br/6209420729895359

2 http://lattes.cnpq.br/9755992709224022
} 
ambiente em que trabalha/reside, e a construção de um estudo da adequação dos mobiliários, posicionamento dos objetos, cores e iluminação essenciais para o desenvolvimento do Home Office na cidade de São Luís.

\section{Palavras-chave:}

Home Office; Intervenção ergonômica; Trabalho remoto; Usuário.

\section{Referências:}

AGÊNCIA BRASIL. IBGE: desemprego na pandemia atinge maior patamar em agosto. Disponível em: <https://agenciabrasil.ebc.com.br/economia/noticia/2020-09/ibge-desemprego-na-pandemia-atingemaior-patamar-em-agosto>. Acesso em: 22 ago. 2021.>

DI MARTINO. V., WIRTH, L. (1990). Telework: A new way of working and living. International Labour Review, 129(5), 529-554.

IIDA, I. GUIMARÃES, L. B. de M. Ergonomia. Projeto e produção. 3a Ed. São Paulo: Blucher, 2016. 850p.

OLIVEIRA, Martha Maria Veras. A ergonomia e o teletrabalho no domicílio. Florianópolis: Dissertação... Universidade Federal de Santa Catarina. ago. 1996. Disponível em: <https://repositorio.ufsc.br/handle/123456789/76935?show=full>. Acesso em: 20 agost. 2021.

OLIVEIRA. R. G., MONT'ALVÃO, C. Metodologias Utilizadas nos Estudos de Ergonomia do Ambiente Construído e Uma Proposta de Modelagem Para Projetos de Design de Interiores. In: Congresso Internacional de Ergonomia e Usabilidade de Interfaces Humano - Tecnologia: Produto, informações, ambientes Construídos e transportes - ERGODESIGN. Recife - PE. UFPE. 2015

REQUENA, Carlos Augusto Joly. Habitar híbrido: interatividade e experiência na era da cibercultura. 2007. Dissertação (Mestrado em Arquitetura e Urbanismo) - EESC-USP - Escola de Engenharia de São Carlos - Universidade de São Paulo, São Carlos, SP.

SANTOS, Simone Martins da Cunha. O Home Office como parte da reestruturação do trabalho no capitalismo pós-moderno. Rio de Janeiro: Universidade Candido Mendes. 2012. 